\title{
Revisiting Christian Missionaries in the Straits Settlements: Blurring the Boundaries between Empire, Mission and Development
}

\author{
Sandra Hudd
}

\begin{abstract}
This article takes two exemplars of Christian missionaries in early colonial Singapore, Penang and Melaka - the London Missionary Society (LMS) (from 1815) and the Infant Jesus Sisters (IJS) (from 1854) - to examine the complex entanglements of missionaries and empire. I argue that they had a wider impact than evangelism and can be usefully conceptualized as faith-based development organizations. The LMS operated the first printing presses in the region and whilst its purpose was evangelical, its translations, technical innovations and printing activities extended its impact. The IJS established schools for girls, an orphanage and a women's refuge, operating as a faith-based organization focused on the education of girls, reduction in child mortality and the empowerment of women. By viewing these early missionaries within a broader context and through the lens of development, their roles as nascent development organizations become more visible.
\end{abstract}

\section{Author}

Sandra Hudd is a University Associate at the University of Tasmania, specialising in Singapore studies and colonial missionaries. Her publications include The Site of the Convent of the Holy Infant Jesus in Singapore: Entwined Histories of a Colonial Convent and a Nation, 1854-2015. In 2016 she was awarded a Fellowship at the National Library Singapore to research early printing in Singapore. She previously worked in humanitarian aid organisations, including the United Nations.

Email: sandra.huddWutas.edu.au 


\section{Keywords}

Straits Settlements; London Missionary Society; Convent of the Holy Infant Jesus; missionaries; humanitarian development; religion in development

\section{Introduction}

Christian missionaries in the British Empire have frequently been portrayed as willing enablers of colonialism and accused of insensitive cultural imperialism. ${ }^{1}$ Frantz Fanon argued in his powerful critique of colonization, The Wretched of the Earth, that a 'colonisation of the mind' occurred in colonial subjects whereby they came to adopt the forms of thought of the colonizer: for Fanon, this included Christianity, with 'the white people's Church, the foreigner's Church' calling the native not to God's way 'but to the ways of the white man, of the master, of the oppressor'. ${ }^{2}$ Increasingly, however, scholars have argued that a simplistic portrayal of missionaries as active imperialists, or at least as complicit in empire, is misleading, and that the relationship between missions and empire was far more complex. Historian Norman Etherington suggested that the linking of mission and empire came about in part because of the contemporaneous expansion of missions and European hegemony, so that missionary work 'tends to be taken for granted as a reflex of imperialism'. ${ }^{3}$ Yet, just as imperial conquest came about in different ways, and the imperial project was manifested in different ways in different locations, so too were missionary endeavours. As literary scholar Anna Johnston has asserted, 'Colonial missionary activities do not constitute a singular evangelical project as opposed to other colonial projects, but different kinds of evangelical, colonial projects in each location they occurred.' ${ }^{\prime}$

A more nuanced picture of the role and impact of missionaries is important and gives us space to re-conceptualize them within the context of development and humanitarian aid. It is increasingly acknowledged that while missions and the official apparatus of empire played related roles in 'the spread of modernization, globalization, and Western cultural hegemony', missions were also often 'pioneers of modern welfare states and international philanthropy'. ${ }^{5}$ Geographer Jenny Lunn notes that the work of charitable religious organizations predates the modern concept of 'development', 6 and has suggested that the marginalization of such organizations within development theory is a legacy of the modernization thesis that separated church and state, and that moving religion from the public to the private sphere obscured their contribution. ${ }^{7}$ Anthropologist Phillip Fountain has gone so far as to describe the field of humanitarian development as 'a child of missionaries' ${ }^{8}$ He argues that 'it has become possible, perhaps even imperative,

\footnotetext{
Porter (1997) summarizes and evaluates the discussion.

Fanon (1965: 34).

Etherington (2005: 1).

Johnston (2003: 31).

Etherington (2005: 4, 261); Barnett (2011); Fountain (2014).

Lunn (2009: 943).

Ibid.: 939.

Fountain (2014: 85).
} 
to relook at history to examine the complicated birth of development in Christian missionary activities' and has called for a research agenda that includes 'a detailed "thick" description of proselytizing and development field encounters'. ${ }^{9}$

This article responds to that call by exploring two exemplars of missionary endeavours in early colonial Singapore, Penang and Melaka (known collectively as the Straits Settlements) from 1826 when they were an administrative unit of the British East India Company (EIC) and, from 1867, a Crown Colony. I look first at the work of the London Missionary Society (LMS), a non-denominational Protestant missionary organization established in 1795 to spread Christianity 'among heathen and other unenlightened nations'.$^{10}$ The LMS came to Melaka in 1815 and to Penang and Singapore in 1819 and remained in the region until the mid-1840s, when the treaty signed after the end of the First Opium War (Anglo-Chinese War) between China and Britain meant that the long 'wait for China' was over and missionaries were able to relocate to Hong Kong and access the Chinese mainland. ${ }^{11}$ Benjamin Keasberry, a missionary with the LMS in Singapore, stayed on, however, no longer officially part of the LMS but in practice continuing the work he had been doing, until his death in 1875. I suggest that we can 'stretch' the historical period of LMS influence to incorporate the years when Keasberry remained in Singapore and continued his work.

The clear focus of the LMS whilst in the region was evangelism. The Society believed in the centrality of the scriptures in Christian worship and hence in the necessity of potential converts being able to read texts in their own local languages. This put the translation and printing of texts at the centre of the LMS missionary endeavour. The LMS did not engage in humanitarian work per se, although it did start several small mission schools in its locations and the larger Anglo-Chinese College in Melaka. However, I will be using development in the broadest sense to argue that their most significant impact was the introduction of a print culture in the region, thus demonstrating that the missionary project sometimes had wider societal impacts than consciously articulated at the time.

Secondly, I turn to a later Catholic mission by French nuns from a teaching order known at the time as the Dames de St Maur or the Charitable Mistresses of the Holy Infant Jesus (and now known as the Infant Jesus Sisters). They arrived in Penang from France in 1852, effectively in transit to Singapore as they waited for sufficient numbers of their Order to arrive. While waiting in Penang, they established the Convent Light School, the first Catholic girls' school in Southeast Asia. ${ }^{12}$ Eventually, in 1854, the Mother Superior and three nuns arrived in Singapore, where their substantial convent complex ultimately included schools for girls, an orphanage and a women's refuge. ${ }^{13}$ Putting their work within the context of today's field of humanitarian aid delivery, it is not too far-fetched to think of them as a nascent faith-based non-government organization, delivering services, raising funds and responding to government requirements and goals. This paper approaches the

\footnotetext{
Ibid.: $87,91$.

Horne (1904: 10).

B. Harrison (1979).

Yap (2001).

13 For a more detailed examination, see Hudd (2016).
} 
analysis of the convent services by drawing on the present-day United Nations Sustainable Development Goals of the education of girls, reduction of child mortality, improvement of health outcomes and the empowerment of women. ${ }^{14}$ It then moves to examine their work in terms of the challenges of fundraising and working within government policies and regulations. In so doing, the paper seeks to make these 'invisible' missionaries more 'visible', and to reposition them within a development paradigm.

\section{Early Printers: The London Missionary Society}

The London Missionary Society, coming out of the great Protestant revival in Britain in the late eighteenth century, favoured a simple form of worship with an emphasis on the scriptures. This centrality of the scriptures meant that Christian texts would need to be translated into a range of local languages, then printed and distributed. In this way, the coming of 'the Word' was to be both a spiritual and practical endeavour, with missionaries not only preaching in languages other than English, but also translating and printing texts.

The first LMS missionaries were sent, unsuccessfully, to the Pacific, although China, with its huge population, was an early destination. Robert Morrison was sent to China in 1807 but restrictions on foreigners meant that he was limited to Canton (now Guangzhou) in the trading season and to Macao at other times. It was illegal to teach Chinese languages to foreigners, and by the time the second missionary, William Milne, arrived in 1813, it was also a capital offence to spread Christianity. Morrison remained in China, but Milne was dispatched to look for another location outside China where the mission could thrive until it became more realistic to return. Melaka was chosen as the base for what would be known as the Ultra-Ganges Mission, encompassing the LMS missions in China (1807), Melaka (1815), Penang (1819), Batavia (now Jakarta) (1819) and Singapore (1819). Melaka had a sizable Chinese population, was relatively close to other Chinese communities and was on a busy maritime trade route, all of which could provide opportunities to build up skills in Chinese languages and potentially enable some publications to get into China by ship. Melaka was also at the time under the control of the British East India Company. ${ }^{15}$ While the EIC had earlier been reluctant to have missionaries on its trading posts, believing that they would interfere with trade and thus profits, it had been forced by the East India Company Act of 1813 to accept them in India, and thus in practice in all areas under its control. They came to be tolerated as long as they did not interfere with trade, particularly as missionaries could provide social services such as schools and hospitals which the Company did not want to fund.

14 The Sustainable Development Goals were agreed by the UN in 2015, replacing the Millennium Development Goals. There are 17 goals and 169 targets. For simplicity, I have used some broad categories which I believe are incorporated into Goal 1 (no poverty), Goal 3 (health), Goal 4 (education) and Goal 5 (gender equality). See https:// sustainabledevelopment.un.org/sdgs, accessed 6 October 2018.

15 Note that Malacca reverted to Dutch control from 1818-25. 


\section{Melaka and Penang}

Milne relocated to Melaka from China in 1815, bringing with him a printer, Liang A-fa (who would subsequently convert to Christianity and become the first indigenous ordained minister in China). ${ }^{16}$ By the time they arrived in Melaka, Milne was proficient in woodblock printing (xylography) which he considered most suitable for printing Chinese characters, having the added advantage of being portable; indeed, Liang A-fa was able to cut the blocks of the first chapter of the Bible book of Genesis on the sea voyage out. ${ }^{17}$ Within two and half months in Melaka, they had produced the first edition of the Chinese Monthly Magazine, a small sixteen-page magazine in Chinese. ${ }^{18}$ It contained evangelical material as well as articles on science and general knowledge, and a 'News Page' of current events in China. It continued to be printed until 1822, initially with 500 copies per issue and later 1,000 copies. ${ }^{19}$ With its innovative 'news page', it has been credited with inspiring emulators in China and thus the beginning of modern journalism there. ${ }^{20}$

Their first printing presses arrived in 1817-a press from Calcutta with English and Malay types, along with six printers; another from England along with a trained printer, Walter Medhurst; and a small portable press from Macao. ${ }^{21}$ By August of the next year they were employing eighteen men and printing in Chinese, Malay and English. ${ }^{22}$ The arrival of the presses and printers allowed output to increase significantly: by the end of 1820, they had produced 140,000 books and periodicals in Chinese and over 20,000 items in Malay. ${ }^{23}$ This included Milne's Zhang Yuan liang you xiang lun (Dialogues between the Two Friends Zhang and Yuan), considered to be 'probably the most frequently reprinted Chinese novel of any kind during the century'. ${ }^{24}$ Their output also included the Indo-Chinese Gleaner, a quarterly magazine in English which contained not only reports of their missionary work but also 'miscellaneous notices relative to the philosophy, mythology, history, and literature of the Indo-Chinese nations, drawn chiefly from the native languages' and which ran from 1817-22. ${ }^{25}$ It is considered to be the 'first completely Western periodical published in the Peninsula'. ${ }^{26}$ When Claudius Henry Thomsen joined the mission to concentrate on Malay, the missionaries also published the first Malay magazine in the region, Bustan Arifin/Malay Magazine from 1821-2, written partly in Romanised Malay and partly in Jawi, an Arabic language adapted for writing in Malay. ${ }^{27}$ Milne died in 1822 but the Chinese translation of the Bible that he had

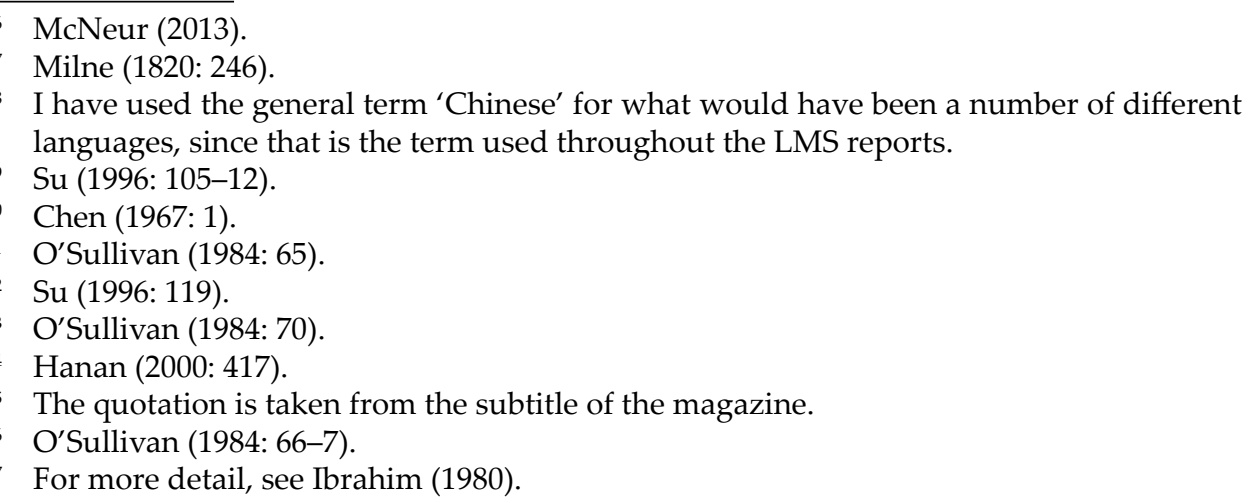


been working on with Morrison was published in Melaka in 1823. It was the first Chinese translation of the Bible to be published in the region and only the second to be published anywhere. ${ }^{28}$

This prolific printing was complemented by their general evangelical work of preaching and handing out Christian tracts, but they also provided some medical services through their dispensary which gave out free medicines and advice. ${ }^{29}$ Within two years of arrival they were also running six schools for boysfour Chinese, one Malay and one for Indians - with children being taught their languages and literature, plus mathematics, by local teachers. ${ }^{30}$ By 1836 there were 220 boys and 120 girls in the Chinese schools and 120 boys and 60 girls in the Malay schools. A school for Chinese women was opened in 1838 and a boarding school for Chinese girls in 1839. ${ }^{31}$

The Anglo-Chinese College was a much more ambitious enterprise. Its General Plan, published in 1818, set out its purpose as 'the reciprocal cultivation of English and Chinese literature', with the hope that it would 'ultimately have a favourable influence on the peaceable diffusion of Christian principles, and the general civilization of the eastern hemisphere'.$^{32}$ European students would learn 'the Chinese language ... for such purposes as the students choose to apply it, to religion, to literature, or to commerce.' 'Native' students would study English, geography, history, arithmetic, 'together with moral philosophy, Christian theology, and their own classics', although it was also clearly stated that 'native youths shall not be required to profess the Christian religion, nor will they be compelled to attend Christian worship'. The College was successful in receiving a grant of 100 Spanish dollars a month from the EIC, as well as donations from a public subscription. ${ }^{33}$ A museum was added in 1823 , by which time the library had already amassed a collection of 3,380 volumes, of which 2,850 were in Chinese. ${ }^{34}$ By 1835 the collection had grown to 4,425 volumes and, with other books collected later, the figure rose higher, so that it 'compared favourably with the libraries of some colleges in the West' ${ }^{35}$

By 1836 the College had 70 students. ${ }^{36}$ It is likely that the local boys attended the college for a range of reasons. They were mostly Peranakan Straits Chinese with Malay mothers and spoke a mixture of Malay and Hokkien. Education in the Chinese classics was highly regarded by families, in part because it taught traditional Confucian values. On a practical level, it was potentially useful in business, as was English which could also assist them in later careers as merchants or as government employees. Stamford Raffles of the EIC was sufficiently impressed to propose that the College be moved to Singapore and incorporated into his newly-envisaged

\footnotetext{
O'Sullivan (1984: 67).

Kua (2018: 79).

Bohr (2001: 174).

Ibid.

Missionary Herald (1819).

O'Sullivan (1988: 46).

Ibid.: 48 .

Kua (2018: 86).

O'Sullivan (1988: 56).
} 
Singapore Institution. This did not come to pass because of problems and delays with establishing the Singapore Institution, but it is indicative of the esteem in which the College was held. When the LMS left Melaka in 1843 and relocated its operations to Hong Kong, the College was also relocated, evolving into the presentday Ying Wa College in Kowloon. ${ }^{37}$

The LMS mission in Penang was established in 1819 and, like the other LMS missions, concentrated on translations and printing, in this case predominantly in Malay, as well as running small schools. Penang at this time was also the site of the well-established Catholic institution, the Collège Général. This had been originally established in Ayutthaya, Siam in 1665 by the Paris Foreign Missions (Société des Missions Etrangères de Paris) and then relocated to Penang in 1806, effectively operating as a seminary for the region. ${ }^{38}$ Father Mathurin Pierre Pécot, who arrived at the Collège Général in 1821, was keen to publish texts in Malay and sent three Malay manuscripts to Paris for printing, but delays there meant that they were not printed until 1826-8. ${ }^{39}$ In contrast, the LMS was substantially better placed to publish evangelical material, having its own printing presses locally, and consequently was the first to publish Christian materials in the area.

\section{Singapore}

The first LMS missionary to Singapore, Samuel Milton, arrived in October 1819, just months after Stamford Raffles' successful negotiation of a treaty to allow the EIC to establish a trading post on the island. Milton had transferred from the Melaka mission and concentrated on Chinese and Siamese translations, and was joined in 1822 by Thomsen, who transferred from Melaka to concentrate on Malay translations. Thomsen brought with him his Malay tutor, Abdullah bin Abdul Kadir. Abdullah, a Muslim who spoke Arabic, Tamil and Malay, had previously tutored Raffles in Melaka and worked for the LMS missionaries there-he was ultimately to work with the LMS for many years, translating and assisting in printing and making his own significant contribution to Malay literature. The missionaries (or often their wives) also started several small schools, the first by Milton soon after arrival-a school for Chinese boys and a Malay school. Others followed over the years; for example, in 1823 Mrs Thomsen started a school for Malay girls with eight pupils, which offered day classes and boarding, teaching reading, writing, arithmetic and sewing, ${ }^{40}$ and in 1827 there were two Malay schools for boys and one for girls, and a Chinese school, ${ }^{41}$ but most schools were short-lived.

Their translation and printing work was the primary focus however, being central to their evangelical purpose. Significantly, too, they had the only printing presses on the island for the first eight years, enabling them to supplement their funds with commercial printing jobs. This included printing Raffles' first proclamations in January 1823 and also doing the printing for the first newspaper,

\footnotetext{
37 http://www.yingwa.edu.hk/about.aspx?clid=180\&atid=1730\&lan=2.

38 Reid (2017).

9 Reid (2009:181-3).

O'Sullivan (1990: 46).

41 London Missionary Society (1827: 35).
} 
the Singapore Chronicle, from 1824-30.42 Their primary purpose, though, was the translation and printing of Christian texts, which they did in Chinese, Malay and Bugis, and which were then handed out around the town and on vessels in the harbour. They also compiled dictionaries which were useful for their own work, as well as used more widely by officials and traders. It was not all smooth going however. Milton was dismissed in 1825, leaving the mission without a Chinese speaker for a period of at least ten years. Thomsen left under somewhat of a cloud in 1834 but, before doing so, claimed that the presses and some land were his own and so sold them to another missionary group, the American Board of Commissioners for Foreign Missions (ABCFM), leaving the LMS without an effective printing set-up.

Fortunately, other more capable members subsequently joined the mission. Benjamin Keasberry, a Malay speaker, joined in 1839, having previously studied printing at the LMS mission in Batavia, where he met American missionaries, subsequently studied theology in New Jersey, and went to Canton with the Americans with the intention of establishing an interdenominational mission. When this proved impossible with the onset of the First Opium War, he relocated to Singapore and joined the LMS, focusing on Malay translations and printing, as well as establishing a school and a Malay Chapel (now the Prinsep Street Presbyterian Church, designated as a National Monument). Keasberry was to become particularly significant after the LMS officially left the region in the 1840s for Hong Kong and China, as he remained behind in Singapore, no longer an LMS missionary per se, but effectively continuing the work he had been doing, until his death in 1875 . He soon moved his small school and printing presses to a plantation that he purchased in River Valley Road, renamed Mount Zion. Pupils studied English and Malay and were instructed in printing and book-binding, with some of the older boys employed in various printing roles. With its instruction in printing and bookbinding, it effectively became the first vocational and technical school in Singapore. ${ }^{43}$

Significantly, Keasberry, with Abdullah's assistance, mastered the lithographic printing of texts in Jawi. He encouraged Abdullah to write his memoir, the Hikayat Abdullah, and published it (in Jawi) in 1849, a text now regarded as a classic of Malay literature. ${ }^{44}$ In an 1860 letter to the LMS Directors, he reported that 'the Mission Press is constantly employed issuing tracts and useful works for distribution and for the use of schools'. He also enclosed a 'Malay quarterly pamphlet which is edited by Rujap who is becoming very useful in this way', writing that 'most of the articles in the work are our own production, written in good idiomatic Malay and are much admired by those who are competent to judge in the language'.$^{45}$ This was the quarterly magazine, the Cermin Mata (The Eyeglass), published from 1858 to 1859 in Jawi, comprising about 100 pages per edition and featuring coloured frontpieces and chapter headings. Keasberry noted that 'most of the young men

\footnotetext{
Gibson-Hill (1953).

Blackburn (2017: 38).

Abdullah (1970).

45 Teo (2009: 290).
} 
formerly educated in the mission school subscribe to it, so by this means we hope to establish a sound and useful literature among the Malays' ${ }^{46}$

Keasberry's lithographic printing in Jawi has been described as a major initiative in Malay publishing, being 'beautifully decorated multi-coloured lithographs, giving a creditable imitation of the rubrication and illumination found in superior manuscripts' and the first printed works that could be comfortably read by literate Malays. ${ }^{47}$ Historian Ian Proudfoot has argued that this new printing technology 'had, in the Muslim world, an impact comparable to that of Gutenberg's typography in the West' ${ }^{48}$ Just as Gutenberg's invention of the printing press in 1440 moved book production out of the monasteries and allowed people, other than the rich, to own books, competent lithographic printing in Jawi meant that literate Malays could access and own printed materials in their own language. Yet, as Proudfoot also noted, these printed works in Jawi and other missionary publications in Malay printed in roman script also influenced Malay literate culture, 'drawing it in the direction of the West'. ${ }^{49}$ Notwithstanding this, it also opened up printing technology to local use-the first local printing of the Quran was done by Muhammad Azhari in 1848 after he purchased a lithographic press in Singapore, perhaps from Keasberry himself, and printed it in Palembang, with his printer being one of the pupil/apprentices from Keasberry's school. ${ }^{50}$

The Mission Press, under Keasberry's direction, was prolific in both Malay and Chinese printing, and supplemented its considerable religious materials with commercial printing. This included the printing of two of the earliest Chinese newspapers in Singapore, the Local News (1845) and the Rising Sun (1858). ${ }^{51}$ Keasberry had been joined in 1842 by Samuel Dyer, an LMS missionary who transferred to Singapore from Melaka. Dyer had been working for some time in Penang and then Melaka on developing a better method for printing in Chinese than the laborious and time-consuming process of creating clay moulds into which metal was poured to create type. Despite not being trained as a printer, Dyer eventually succeeded in the complex task of creating suitable metal cast fonts. He is credited with being the first person to successfully do so, representing 'a critical transformation from xylography to typography in the history of Chinese printing' ${ }^{52}$ The small day and boarding school for Chinese girls started by Dyer's wife, Maria, might well have been another short-lived attempt at education when her husband died the next year and she left the mission, but it was saved from closure by being taken over by the Society for the Promotion of Female Education in China, India and the East and evolved into St Margaret's School, which still exists today.

\footnotetext{
46 Ibid.

47 Proudfoot (1993: 14).

48 Proudfoot (1998: 131).

49 Ibid.

$50 \quad$ Ibid.: 127.

51 Lee (2018: 70-1).

$52 \mathrm{Su}(1996: 151)$.
} 


\section{Quiet Missionaries: Catholic Nuns as Change-Agents in Colonial Singapore}

In 1854, with the LMS having left Singapore and only Keasberry remaining, Catholic nuns from the French teaching order the Charitable Mistresses of the Holy Infant Jesus arrived in Singapore from Penang to establish their Convent of the Holy Infant Jesus (CHIJ). Their primary focus was to start up a school for girls, with the larger purpose of increasing the spread of Catholicism in the region. Father Beurel, the local Catholic priest who was instrumental in bringing the Sisters to Singapore, along with the De La Salle Brothers (Christian Brothers), had been clear about this. In June 1848 he had penned a public appeal for funds for a boys' school, addressed 'to all friends of Christian civilization', writing that funds were needed so that he could introduce the Christian Brothers teaching 'into this part of the world, where Christianity and Civilization are yet so little diffused among the Natives' ${ }^{53}$ In this, we clearly see the ideological interconnectedness between imperialism, religion and the civilizing mission.

Nonetheless, it was clear from the beginning that the needs in the community were greater than just schooling: tenements were overcrowded, poor drainage and water pollution caused disease, and poverty, opium use and prostitution were widespread. The laissez-faire approach of the EIC worked well for free trade and thus profits, but meant that social services were minimal. Immediately, the Sisters found that young children were being left at the convent gate and soon they found themselves running an orphanage, school, women's refuge, and later even taking over the running of the government hospital.

Just as the missionary wives of the LMS were generally missing from the accounts of the Strait Settlement missions and hence 'stranded in something of an historiographical lacuna', ${ }^{54}$ the role of Catholic nuns as missionaries has often been unacknowledged. The preconception of the nun as handmaiden to a patriarchal Church has meant that they have often been portrayed as passive participants in mission, so that, as historian Susan O'Brien has argued: 'They have less often been described as agents in their own right: as the missionaries, property owners, liturgists, educational policy makers and spiritual directors that many of them undoubtedly were. ${ }^{55}$ I suggest that, behind the convent walls, these 'missing' missionaries were actively establishing and delivering community services that were forerunners of modern educational and social services in Singapore. We can reconceptualize their work within the context of today's development goals.

\section{Reducing Child Mortality}

Unbidden, the Sisters found that babies were being left at the convent gatesixteen children were taken in on the first day. Numbers continued to rise steadily over the years: there were, for example, 93 in 1861 and 200 in 1892 (and as many as

\footnotetext{
For the full text, see Wijeysigha and Nicolas (2006: 221).

Doran (1996: 101).

55 O’Brien (1997: 180).
} 
400 in 1936)..$^{56}$ It is difficult to know the precise circumstances that led to parental decisions to leave a child at the convent. Researcher Genevieve Wong studied the burial register for the Bidadari Christian Cemetery where children from the convent were buried. She found that 80 per cent of all infants under one year of age buried there were from the convent, suggesting that most were near death at the time of abandonment. ${ }^{57}$ Poor families, realizing that a child was near death, may have abandoned a child at the gate simply in the hope that the nuns might be able to give them better care, or knowing that at least the child would be properly buried. Wong also estimated that 467 of the 480 buried infants from the convent were Chinese. ${ }^{58}$ Historian Henrietta Harrison, writing about the interactions between Chinese families and Catholic orphanages in China, noted that it was believed that a child who died young would be a wandering ghost who might return to inhabit the body of a younger sibling. Christian baptism, with the child going to a special Christian heaven, 'fitted easily into the repertoire of techniques for dealing with ghosts' ${ }^{59}$ Other cultural factors also seem to have played a part. Wong found that two-thirds of the buried infants were girls. ${ }^{60}$ This suggests that a preference for boys in a male-centred and patriarchal community led to the higher likelihood of girls being abandoned, a practice further exacerbated by superstitions about the bad luck attached to girls born in the astrological Year of the Tiger (which occurred every 12 years). Such 'tiger girls' were believed to be destined to be rebellious and troublesome, causing trouble in the family and not likely to make good, obedient wives and daughters-in-law. ${ }^{61}$

As in the convent schools, we see in the orphanage programme the mixture of secular and religious aims. The impetus for the care of children was humanitarian and the quality of care in the orphanage was regularly praised by visitors in the local newspapers. Most of the girls left with at least a primary school education and some vocational and domestic skills. Yet at the same time as the Sisters operated a programme that helped to reduce child mortality and cared for vulnerable children, they were also engaged in 'saving souls'. Dying infants were baptised as Catholics and given Catholic names. Orphans growing up in the convent attended Catholic mass, and their marriages to young Catholic men, which the nuns helped to organize, increased the population of Catholics in Singapore. This is the difficult mix, the potentially porous border between Christian evangelism and humanitarian aid, that still challenges some faith-based development organizations today. ${ }^{62}$

56 Numbers for 1854, 1892 and 1936 from Meyers (2004: 62, 249). Numbers for 1861 from Liew (1993). All numbers should be treated with some caution as it is usually not specified if they were the total number of new arrivals for the year, including those who had died, or the actual number in residence at unspecified dates.

57 G. Wong (2010/11: 22).

58 Ibid.

59 H. Harrison (2008: 83).

60 G. Wong (2010/11: 22).

61 Hudd (2016: 34-5).

62 Hoffstaedter (2011). 


\section{The Education of Girls}

When the Sisters arrived in Singapore, there was only one mission school for girls still operating, the Chinese Girls' School which had been started by the LMS and continued by the Society for the Promotion of Female Education in the East. The Sisters opened their school for girls within ten days of their arrival, with fourteen European and Eurasian students, plus a handful of orphans supported by the fees paid by the other students. By 1862 it had grown to 145 boarders and day-students, 82 of whom were non-fee-paying. ${ }^{63}$ The next year, the school was divided into two sections - one for fee-paying children and one for 'the poorer classes of society' who received education 'more consistent with their social status' ${ }^{64}$ This reflected the social reality of the time, as expressed in the 1870 Legislative Council Select Committee enquiry into education which commented broadly that

The education imparted in several (female schools), causes the pupils to imbibe ideas above their stations, and renders them discontented when they return to their homes. They are thereby unfitted for the duties they are expected to perform, and, unless fortunate enough to marry, often fall to a lower condition in life that that to which they originally belonged. ${ }^{65}$

The Sisters then were not radicals, they were not expressly challenging social norms. As philosopher Michel Foucault famously argued, schools are inherently part of the 'disciplinary society' - like the orphanage and, I suggest, the convent, they are means of social control.$^{66}$ Yet, by the very act of establishing and running the girls' school, and later from 1933, a school for Chinese girls, the Sisters were contributing to changing the society around them by opening up education - and thus ideas and opportunities - for girls.

\section{Empowerment of Women}

The other significant programme run at the convent was a shelter for women rescued from prostitution and forced marriage. The number of women coming from China had increased from the 1860s, with thousands being brought to Singapore for the brothels or to be sold as domestic workers. There were 60 women in residence at the convent refuge in 1870 and 200 in $1872 .{ }^{67}$ Many of the women and children in the convent refuge were eventually baptised, and the nuns also tried to arrange for their marriage to suitable Christian spouses. As with other aspects of their services, we see again an interweaving of the conversion impulse and the humanitarian.

In a broader sense of course, the Sisters ultimately empowered the girls by educating them and the women by providing a place of refuge and, perhaps also to some extent, by modelling the possibility of roles for women outside of the home.

\footnotetext{
3 Gwee et al. (1969: 19).

64 Wijeysigha and Nicolas (2006: 237).

65 The report is reproduced in full in Wong and Gwee (1980), pp. 11-14.

66 Foucault (1977).

67 Liew (1993: 44-5).
} 
This is the paradox of the nun: simultaneously operating within a hierarchical and controlled institution of the church-obedient and constrained-yet, to some extent at least, also operating outside of the gendered norms of the time. The sisters had chosen their vocation and, particularly in the early years of the convent, had chosen to leave their families to make the difficult and often dangerous trip to Singapore. It had taken three attempts to even get the first sisters to Singapore. The first group of four had left from Antwerp in December 1851 but their ship was nearly wrecked while still in the English Channel, the Mother Superior fell ill and died on route, and the journey took five months. The second group which left almost a year later went by boat to Egypt, joined a camel caravan to cross the desert to Suez, then boarded another ship to Penang, where they established the convent and school while waiting for the third group to arrive a year later. It surely took a measure of courage to leave all behind and to risk their lives to travel to the 'Far East'. Later, nuns from other countries joined them, particularly nuns from Ireland after the early 1900s. Indeed, historian Deidre Raftery has argued that orders of women religious were the first all-female transnational networks, with thousands of women mobilized and sustained by networks of contacts. ${ }^{68}$ Teaching orders became in a sense global networks, with nuns and resources moving between countries, while letters and magazines shared advice and mutual support.

\section{Improving Health Outcomes}

The Sisters, as a teaching rather than a nursing order, were not explicitly providing health services per se. Yet the care of the babies and older orphans inevitably required a measure of nursing care. Despite the high number of deaths of very young babies abandoned at the gate, many children were nursed back to health. The quality of care of the children seems to have been considered as good. A visitor to the convent in 1897 reported in the Straits Times newspaper that the orphans 'were entirely without the desponding look which one often sees in orphanages', and that 'I cannot do justice to the admirable arrangements here. ${ }^{\prime 69}$

Unusually for a teaching order, the Sisters branched out to run the Singapore General Hospital from 1885 to 1903. There had been concerns about the standards of the hospital and the Bishop had been considering setting up an alternative hospital. The Governor, on hearing of these plans, approached the Bishop to provide nuns to run the general hospital instead. ${ }^{70}$ In this way, the placement of the nuns in the hospital as nurses was not dissimilar to the work of medical nongovernment organizations today-providing staff and also training and building the capacity of local staff.

\section{Fundraising}

To support the convent programmes, the Reverend Mother had, like all CEOs, to raise funds and manage finances. School fees provided some income, as did the

\footnotetext{
68 Raftery (2015).

69 Straits Times (1897).

70 Meyers (2004: 248).
} 
sale of the needlework and sewing done by the nuns. 'Fancy bazaars' and concerts were also organized, being both social occasions for the wider community and serious fundraising concerns. The Reverend Mother had to be adept at fundraising in all of these ways and in cultivating positive relations with government officials, key merchants and other influential persons and groups who might be willing and able to support the work of the convent. One of their benefactors was the Chinese merchant Cheang Hong Lim, who donated the significant sum of $\$ 3000-$ one-tenth of the total-towards the construction of a new school building that opened in 1892. The opening of that building was attended by the Monsignor, the Governor, the Sultan of Johore and the Consuls of France, Italy, Spain, Germany, Holland and Russia, attesting to the status and reputation of the convent school, as well as the successful networking efforts of the nuns. The report of the event in the Singapore Free Press and Mercantile Advertiser recognized this, noting that the Reverend Mother's 'wise guidance' of the affairs of the convent 'unquestionably require no small business capacity, discretion and judgement' ${ }^{\prime 1}$

Interestingly, the discretion and judgement over the years included accepting assistance from other faiths. The fanlight windows above the doors in the orphanage have a representation of the Buddha in each one, having been donated by the Buddhist Association, while some of the iron staircases in the convent display Islamic designs. ${ }^{72}$ This suggests a tolerance between religious faiths-towards Catholicism by Buddhists and Muslims, and by the Sisters, who presumably took a pragmatic view and saw no difficulty in incorporating symbols of these other faiths in their architecture.

The convent also received some funds from the Holy Childhood Association (l'Oeuvre de la Sainte Enfance). This organization, established in France in 1843, was open to French children under twelve years of age who agreed to give small monthly donations so that Catholic missionaries in China could baptise abandoned children and raise them in Christian families. By 1869 the Association's annual income was almost two million francs. Membership had spread to Europe and North America; its journal was printed in fourteen languages; and it supported children in China, Indochina, Africa and Southeast Asia. ${ }^{73}$ Harrison has suggested that the Holy Childhood Association is one of the earliest examples of a transnational aid organization, predating the International Red Cross which was established in the 1860s. She also suggested that central to its appeal was the idea of the power of French Christian children over the pagan Chinese-a 'power through weakness' that 'spoke not only of family and sentiment, but also of France and missions and empire, of the exotic and oriental transformed by Christian children' ${ }^{74}$ Here again we see the enmeshment of humanitarianism and evangelism.

\footnotetext{
Singapore Free Press and Mercantile Advertiser (1892).

72 Preservation of Monuments Board (2012).

3 H. Harrison (2008).

74 Ibid.: 79.
} 


\section{Government Liaison and Regulation}

Just as with non-government organizations today, the convent increasingly had to liaise with government and adapt to its funding and policy requirements. It was in education that increasingly regulation came into play, particularly after the Straits Settlements became a Crown Colony in 1867, answering directly to the Colonial Office. The first Inspector of Schools was appointed in 1872 and, after an inspection in 1881, the Convent school was officially classed as a 'government-aided school' and became eligible for government funding. ${ }^{75}$ This brought with it requirements to comply with government education policies. Because public funds could not be used for proselytising, religious instruction could only take place before or after official school hours. From 1886 the government began to provide grants to girls' schools based on the number of passes obtained and the number of students. This, along with changing social attitudes towards education for girls, led to an enlarged curriculum and increased enrolment. The government also introduced a grading system for schools in 1899, based on their academic standards. The convent school was classified Grade $1,{ }^{76}$ suggesting that from early days, the school was developing as a respected and elite institution. By the early 1900s the government had established an Education Code and an Education Board and had greatly increased its expenditure on education. In 1904 the Convent students sat for the first Junior Cambridge examinations, and in the next year prepared for the Senior Cambridge examinations, which would mark the start of the Convent's secondary school. By the end of the 1920s, the Convent school had introduced geography, literature, history, algebra, geometry, science, shorthand, typing and book-keeping, as well as extra-curricular activities such as physical training, and sports such as netball. ${ }^{77}$

To cater for the increasing numbers of Chinese students from about the early 1900s, the Sisters bought the adjoining Hotel Van Wijk in 1931. While the hotel was purchased to provide additional facilities, it also had a related moral dimension: it was thought that the building might otherwise be knocked down and replaced by a high building, 'the vicinity of which could be a moral danger for our boarders as their dormitory is very close to the land' ${ }^{78}$ It reopened in 1933 as a school for Chinese girls, with forty students in two primary school classes, and within the first few years, enrolment more than doubled. By 1936 it provided a full primary school education, and by 1941 a full secondary education. The post-colonial period is outside of the scope of this paper, but of course independence brought with it different priorities and educational policies for the new nation, and thus new challenges for the convent schools. The fact that there are eleven CHIJ schools in Singapore today is testament to their ability to adapt and survive, and also to their contribution to the development of education in Singapore.

Wijeysigha \& Nicolas (2006: 237).

Gwee et al. (1969: 27).

Kong, Low and Yip (1994: 65).

Ibid.: 62-3. 


\section{Conclusion: Rethinking Roles}

The LMS and the Convent of the Holy Infant Jesus were both important missionary bodies in early colonial Singapore and Malaya, making it useful to look again at the roles they played, and to ask whether they operated, at least in some ways, as early or nascent development agencies. Of my two case studies, the Convent fits most neatly into this hypothesis. From within the Convent walls, the Sisters actively contributed to what in today's context we would define as the development goals of universal education for girls, reduction in child mortality, improvement of health outcomes and the empowerment of women. They were engaged in what they saw as the task of 'saving souls', yet they were also firmly engaged in assisting women and children in need and in the development of education and social services in Singapore (and Penang). Their funds and teaching staff (nuns) came through their transnational networks, with their work predating the formation of the International Committee of the Red Cross in 1863. It is not an exaggeration to describe them as operating as an early faith-based development organization which, whether clearly conceptualized and articulated or not, worked to achieve key humanitarian goals. Today, such organizations might more clearly differentiate, and separate, their evangelical and humanitarian activities, particularly if seeking government funding. Yet, including Catholic religious Sisters in the ambit of development serves to position the education and social work of the Sisters in a broader context. I suggest that they are a powerful historical example of a development organization, operating at an earlier time and in a different way than we might otherwise envisage.

LMS missionaries on the other hand, while opening small schools and the Anglo-Chinese College, were primarily engaged in translation and printing of Christian materials. This work was largely evangelical in intent, yet it also effectively introduced the printing press and thus mass communication to the Straits Settlements. We can thus place them within a broader scope of development, in that their printing of texts - religious, government and commercial, as well as their training of local printers - was instrumental in bringing a print culture to the region. The introduction of the printing press, as in other parts of the world, ultimately meant that books became cheaper and more widely distributed and that magazines and newspapers brought ideas and news to people in the region. Political scientist Benedict Anderson famously argued that because newspapers allowed people in an area to read the same information, they came to think of themselves as part of a larger, shared community. ${ }^{79}$ This 'imagined community' or shared consciousness, he theorized, enabled a sense of a 'deep horizontal comradeship' between people who would never know each other in person but who came to think of themselves as part of a broader community, and ultimately as part of a nation - that is, the nation as social construct. The LMS missionaries, in the service of the spread of Christianity primarily but also undertaking government and commercial printing, were the first printers of note in the region and, significantly, translated and printed in the vernacular. While their links to the British project of empire were inevitable, they also helped to bring a print culture to the region and

79 Anderson (2006). 
ultimately a more literate community exposed to new ideas and the means to share news and opinions.

Re-examining the work of the LMS and the IJS in Malaya and Singapore is not to excuse or downplay the darker side of empire. Missionaries were part of the larger spread of Western influence and ideas, and mission schools undoubtedly did crucial work in the empire-building process. In some parts of the world, missionaries were blatantly insensitive to local cultures and, while this was not the case per se with the two examplars in this paper, they were committed to the task of widespread conversion to Christianity and hence as what was considered at the time as bringing 'civilization' to the region. In the process, with their schools, orphanages, refuges and printing presses, they were also forerunners, even if flawed, of faith-based development organizations and, like many modern humanitarian faith-based organizations, had to navigate the porous borders between Christian evangelism and social development.

\section{References}

Abdullah bin Abdul Kadir (1970), The Hikayat Abdullah: An Annotated Translation, transl. A. H. Hill, Kuala Lumpur: Oxford University Press. Original edition, 1849.

Anderson, Benedict (2006), Imagined Communities: Reflections on the Origin and Spread of Nationalism, rev. edn, London: Verso. Original edition, 1983.

Barnett, Michael (2011), Empire of Humanity: A History of Humanitarianism, Ithaca: Cornell University Press.

Blackburn, Kevin (2017), Education, Industrialization and the End of Empire in Singapore, New York: Routledge.

Bohr, P. Richard (2001), 'The Legacy of William Milne', International Bulletin of Missionary Research, 25/4: 173-8.

Chen Mong Hock (1967), The Early Chinese Newspapers of Singapore 1881-1912, Singapore: University of Malaya.

Doran, Christine (1996), "“A Fine Sphere of Female Usefulness": Missionary Women in the Straits Settlements, 1815-45', Journal of the Malaysian Branch of the Royal Asiatic Society, 69/1: 100-11.

Etherington, Norman (ed.) (2005), Missions and Empire, Oxford: Oxford University Press.

Fanon, Frantz (1965), The Wretched of the Earth, transl. Constance Farrington, London: Macgibbon and Fee.

Foucault, Michel (1977), Discipline and Punish: The Birth of the Prison, trans. Alan Sheridan, London: Penguin.

Fountain, Philip (2014), 'Proselytizing Development', in Emma Tomalin, The Routledge Handbook of Religions and Global Development, Abingdon, Oxon.: Routledge, pp. 80-98.

Gibson-Hill, C. A. (1953), 'The Singapore Chronicle (1824-37)', Journal of the Malayan Branch of the Royal Asiatic Society, 26/1: 175-99.

Gwee Yee Huan, Joseph Doray, K. M. Waldhauser, and Ahmad Zahoor (1969), 150 Years of Education in Singapore, Singapore: TCC Publications Board.

Hanan, Patrick (2000), 'The Missionary Novels of Nineteenth-Century China', Harvard Journal of Asiatic Studies, 60/2: 413-43. 
Harrison, Brian (1979), Waiting for China: The Anglo-Chinese College at Malacca, 18181843, and Early Nineteenth-Century Missions, Hong Kong: Hong Kong University Press.

Harrison, Henrietta (2008), "'A Penny for the Little Chinese": The French Holy Childhood Association of China, 1843-1951', American Historical Review, 113/1: 72-92.

Hoffstaedter, Gerhard (2011), Religion and Development: Australian Faith-Based Development Organisations, ACFID Research in Development Series, Report no. 3, Melbourne: ACFID.

Horne, C. Silvester (1904), The Story of the L.M.S. with an appendix bringing the story up to the year 1904, Blackfriars: London Missionary Society.

Hudd, Sandra (2016), The Site of the Convent of the Holy Infant Jesus in Singapore: Entwined Histories of a Colonial Convent and a Nation, 1854-2015, Lanham: Lexington Books.

Ibrahim bin Ismail (1980), 'In Quest of the Malay Magazine (1821-22)', Indonesia and the Malay World, 8/21: 45-8.

Johnston, Anna (2003), Missionary Writing and Empire, 1800-1860, Cambridge: Cambridge University Press.

Kong, Lily, Low Soon Ai, and Jacqueline Yip (1994), Convent Chronicles: History of a Pioneer Mission School for Girls in Singapore, Singapore: Armour Publishing.

Kua, Paul (2018), 'The Anglo-Chinese College in Malacca, 1818-1843: Its Location and Facilities', Journal of the Malaysian Branch of the Royal Asiatic Society 91/1: 69-88.

Lee Ching Seng (2018), 'A Historical Perspective of Singapore's Changing Role in Early Printing in the Chinese Language, 1825-1902', in Chapters on Asia: Selected Papers from the Lee Kong Chian Research Fellowship (2014-2016), Singapore: National Library Board, pp. 57-91.

Liew, Clement (1993), 'The Roman Catholic Church of Singapore 1819-1910: From Mission to Church', unpublished thesis, National University of Singapore.

London Missionary Society (1827), The Report of the Directors to the thirty-third general meeting of the Missionary Society, usually called the London Missionary Society, on Thursday, May 10, 1827, London: London Missionary Society.

Lunn, Jenny (2009), 'The Role of Religion, Spirituality and Faith in Development: A Critical Theory Approach', Third World Quarterly, 30/5: 937-51.

McNeur, George Hunter (2013), Liang A-fa: China's First Preacher, 1789-1855, Eugene: Pickwick Publications. Original edition, 1934.

Meyers, Elaine (2004), Convent of the Holy Infant Jesus: 150 Years in Singapore, Penang: The Lady Superior of Convent of the Holy Infant Jesus.

Milne, William C. (1820), Retrospect of the First Ten Years of the Protestant Mission to China (Now in connection with the Malay, Denominated, the Ultra-Ganges Missions); accompanied with miscellaneous remarks on the literature, history and mythology of China, Ec., Malacca: Anglo-Chinese Press.

Missionary Herald (1819), 'Anglo-Chinese College', XV/4.

O'Brien, Susan (1997), 'French Nuns in Nineteenth Century England', Past and Present, 154: 142-80.

O'Sullivan, Leona (1984), 'The London Missionary Society: A Written Record of Missionaries and Printing Presses in the Straits Settlements, 1815-1847', Journal of the Malaysian Branch of the Royal Asiatic Society, 57/2: 61-104. 
(1988), 'The Anglo-Chinese College and the Early "Singapore Institution"', Journal of the Malaysian Branch of the Royal Asiatic Society, 61/2: 45-62.

(1990), 'A History of the London Missionary Society in the Straits Settlements (c. 1815-1847)', Unpublished PhD thesis, University of London.

Porter, Andrew (1997), "Cultural Imperialism” and Protestant Missionary Enterprise 1780-1914', Journal of Imperial and Commonwealth History, 25/3: 36791.

Preservation of Monuments Board, Singapore (2012), 'Monuments Open House 2012', unpublished.

Proudfoot, Ian (1993), Early Malay Printed Books: A Provisional Account of Material Published in the Singapore-Malaysia Area up to 1920, noting holdings in major public collections, Kuala Lumpur: University of Malaya.

(1998), 'Lithography at the Crossroads of the East', Journal of the Printing Historical Society, 27: 113-31.

Raftery, Deidre (2015), 'Teaching Sisters and Transnational Networks: Recruitment and Education Expansion in the Long Nineteenth Century', History of Education, $44 / 6: 717-28$.

Reid, Anthony (2009), 'Fr Pécot and the Earliest Catholic Imprints in Malay', in Jan van der Putten and Mary Kilcline Cody (eds), Lost Times and Untold Tales from the Malay World, Singapore: NUS Press, pp. 177-85.

(2017), 'Regional Networks of Knowledge: The Penang Collège Général and Beyond', in Peter Zabielskis, Yeoh Seng Guan and Kat Fatland (eds), Penang and Its Networks of Knowledge, Penang: Areca Books, pp. 61-81.

Singapore Free Press and Mercantile Advertiser (1892), 'The Convent', 2 July, p. 4.

Straits Times (1897), 'The Convent: Impressions of a Visitor', 14 December.

$\mathrm{Su}$, Ching (1996), The Printing Presses of the London Missionary Society among the Chinese, Unpublished PhD thesis, School of Library, Archive and Information Studies, University of London.

Teo Eng Liang (2009), Malay Encounter during Benjamin Peach Keasberry's Time in Singapore, 1835 to 1875, Singapore: Trinity Theological College.

United Nations. Sustainable Development Goals. https://sustainabledevelopment. un.org/sdgs, accessed 6 October 2018.

Wijeysigha, Eugene and Rene Nicolas (2006), Going Forth: The Catholic Church in Singapore 1819-2004, Singapore: Commissioned and Published by His Most Rev. Nicolas Chia, Titular Roman Catholic Archbishop of Singapore.

Wong, Francis and Gwee Yee Hean (eds) (1980), Official Reports on Education: Straits Settlements and the Federated Malay States, 1870-1939, Singapore: Pan Pacific Book Distributors.

Wong, Genevieve (2010/2011), Grave Matters: The Burial Registers and Singapore History, unpublished thesis, National University of Singapore.

Yap, Dilys (2001), The Convent Light Street: A History of a Community, a School and a Way of Life, Penang: Dilys Yap.

Ying Wa College. http://www.yingwa.edu.hk/about.aspx?clid=180\&atid=1730\&lan =2, accessed 2 February 2019. 